\title{
Potentiation of Glibenclamide-Induced Insulin Release by Calcium Infusion*
}

\author{
L. Gero, É. Baranyi, K. Steczek, Gy. Petrányi jr., and Gy. Tamás jr. \\ 1st Department of Medicine, Semmelweis University, Budapest, Hungary
}

\begin{abstract}
Summary. The effect of calcium on glibenclamideinduced insulin release was studied in 14 diabetic patients. Two $\mathrm{mg}$ glibenclamide was given intravenously and calcium, blood glucose and IRI were determined in venous blood samples at predetermined intervals. The test was repeated 3-4 days later with the patients simultaneously receiving a calcium infusion into a contralateral vein. The decrease in blood glucose and the rise in IRI level were both significantly greater in the combined glibenclamide-calcium test. It is concluded that calcium may temporarily improve carbohydrate tolerance in diabetic patients by potentiating the glibenclamide-stimulated insulin secretion.
\end{abstract}

Key words: Blood glucose, calcium, IRI, glibenclamide, diabetic patients.

The importance of calcium ions for insulin secretion is well established from studies in vitro using isolated perfused rat pancreas [2], pieces of rabbit pancreas [18], and organ cultures of fetal rat pancreas [12]. Calcium had no influence on the incorporation of radioactive amino acids into pancreatic hormones, indicating that calcium is required for insulin release rather than for biosynthesis of the hormone [4]. A possible mechanism for the calcium effect has been suggested by Malaisse and coworkers $[16,17]$.

In spite of this well-documented role of calcium in insulin secretion in vitro, data concerning humans, especially diabetics, are few and contradictory. Therefore we studied the influence of acutely induced hypercalcaemia on the hypoglycaemic and insulinotrophic action of glibenclamide.

\footnotetext{
* Presented in part at the 12th Annual Meeting of the European Association for the Study of Diabetes, Helsinki 1-3 Sept. 1976
}

\section{Patients and Methods}

The study was performed in 14 hospitalized diabetic patients. At the time of the study eleven of them were controlled by diet or diet + antidiabetic drugs and three were treated with small doses of insulin (Table 1). (Subsequently all three patients were treated with oral hypoglycaemic agents.) After one day without drugs and an overnight fast patients received $2 \mathrm{mg}$ glibenclamide intravenously as a bolus

Table 1. Individual data of patients included in the study

\begin{tabular}{|c|c|c|c|c|c|}
\hline 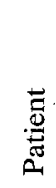 & 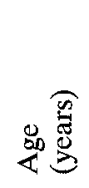 & 希 & 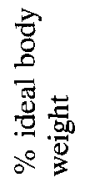 & 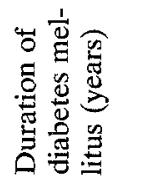 & Treatment (dose $/ 24$ h) \\
\hline 1. & 68 & $\mathrm{~F}$ & 140 & 11 & diet \\
\hline 2. & 50 & $\mathrm{~F}$ & 135 & 1 & diet \\
\hline 3. & 68 & $\mathrm{~F}$ & 134 & 1 & diet \\
\hline 4. & 63 & M & 110 & 8 & $\begin{array}{l}\text { Glibenclamide } 15 \mathrm{mg} \\
\text { Buformin } 300 \mathrm{mg}\end{array}$ \\
\hline 5. & 33 & $\mathbf{M}$ & 125 & 3 & $\begin{array}{l}\text { Carbutamide } 1,0 \mathrm{~g} \\
\text { Buformin } 50 \mathrm{mg}\end{array}$ \\
\hline 6. & 54 & $\mathrm{~F}$ & 130 & 6 & $\begin{array}{l}\text { Glibenclamide } 15 \mathrm{mg} \\
\text { Buformin } 300 \mathrm{mg}\end{array}$ \\
\hline 7. & 52 & $\mathrm{~F}$ & 140 & $\begin{array}{l}\text { newly } \\
\text { discovered }\end{array}$ & diet \\
\hline 8. & 55 & M & 106 & 5 & $\begin{array}{l}\text { Glibenclamide } 15 \mathrm{mg} \\
\text { Buformin } 300 \mathrm{mg}\end{array}$ \\
\hline 9. & 53 & $\mathrm{~F}$ & 180 & 3 & diet \\
\hline 10. & 76 & $\mathrm{~F}$ & 105 & 10 & $\begin{array}{l}\text { Glibenclamide } 15 \mathrm{mg} \\
\text { Buformin } 300 \mathrm{mg}\end{array}$ \\
\hline 11. & 50 & $\mathrm{~F}$ & 116 & 15 & $\begin{array}{l}\text { Glibenclamide } 15 \mathrm{mg} \\
\text { Buformin } 300 \mathrm{mg}\end{array}$ \\
\hline 12. & 59 & M & 123 & 6 & 28 U Semilente (Novo) \\
\hline 13. & 52 & $\mathrm{~F}$ & 117 & 6 & $\begin{array}{l}20 \mathrm{U} \text { Zinc-protamine } \\
\text { insulin (Richter) }\end{array}$ \\
\hline 14. & 76 & $\mathrm{~F}$ & 130 & 11 & $\begin{array}{l}20 \text { U Zinc-protamine } \\
\text { insulin (Richter) }\end{array}$ \\
\hline
\end{tabular}


Table 2. Changes in serum calcium and blood glucose in the 3 insulin-treated patients following the glibenclamide and glibenclamide + calcium administration

\begin{tabular}{|c|c|c|c|c|c|c|c|c|c|c|c|c|c|c|c|c|c|c|}
\hline \multicolumn{10}{|c|}{$\mathrm{Ca}(\mathrm{mg} / 100 \mathrm{ml})$} & \multicolumn{9}{|c|}{ Glucose $(\mathrm{mg} / 100 \mathrm{ml})$} \\
\hline $\min$ & 0 & 15 & 30 & 45 & 60 & 90 & 120 & 180 & 240 & 0 & 15 & 30 & 45 & 60 & 90 & 120 & 180 & 240 \\
\hline \multirow[t]{2}{*}{13.} & 9.2 & 9.2 & 9.5 & 9.2 & 9.3 & 9.0 & 9.5 & 9.3 & 9.4 & 312 & 310 & 290 & 282 & 296 & 258 & 254 & 198 & 174 \\
\hline & 9.1 & 10.5 & 12.2 & 13.4 & 14.2 & 13.7 & 13.1 & 12.9 & 12.7 & 275 & 247 & 214 & 200 & 200 & 149 & 145 & 122 & 121 \\
\hline \multirow[t]{2}{*}{14.} & 10.8 & 10.1 & 9.8 & 9.8 & 9.6 & 10.7 & 10.4 & 10.7 & 11.0 & 262 & 267 & 269 & 265 & 220 & 255 & 227 & 214 & 241 \\
\hline & 10.3 & 11.6 & 12.2 & 12.8 & 12.5 & 12.0 & 11.8 & 11.7 & 11.1 & 252 & 224 & 224 & 207 & 195 & 162 & 153 & 135 & 135 \\
\hline \multirow[t]{2}{*}{12.} & 9.2 & 8.7 & 8.1 & 8.1 & 8.2 & 8.2 & 8.2 & 8.1 & 8.2 & 226 & 230 & 226 & 219 & 231 & 200 & 182 & 149 & 142 \\
\hline & 8.9 & 9.9 & 10.3 & 10.9 & 11.6 & 12.8 & 13.1 & 11.9 & 11.2 & 237 & 237 & 224 & 219 & 196 & 165 & 145 & 90 & 82 \\
\hline
\end{tabular}

Table 3. Significance of the decreases in serum calcium during the glibenclamide test

\begin{tabular}{|c|c|c|c|c|c|c|c|c|c|}
\hline $\min$ & 0 & 15 & 30 & 45 & 60 & 90 & 120 & 180 & 240 \\
\hline $\begin{array}{l}\text { Ca mg/100 ml } \\
\mathrm{P}<\end{array}$ & $9.9 \pm 0.7$ & $\begin{array}{l}9.5 \pm 0.8 \\
0.7\end{array}$ & $\begin{array}{l}9.2 \pm 0.8 \\
0.01\end{array}$ & $\begin{array}{l}9.2 \pm 0.9 \\
0.001\end{array}$ & $\begin{array}{l}9.2 \pm 0.8 \\
0.001\end{array}$ & $\begin{array}{l}9.3 \pm 0.9 \\
0.001\end{array}$ & $\begin{array}{l}9.4 \pm 0.9 \\
0.01\end{array}$ & $\begin{array}{l}9.5 \pm 1.0 \\
0.1\end{array}$ & $\begin{array}{l}9.5 \pm 0.9 \\
0.1\end{array}$ \\
\hline
\end{tabular}
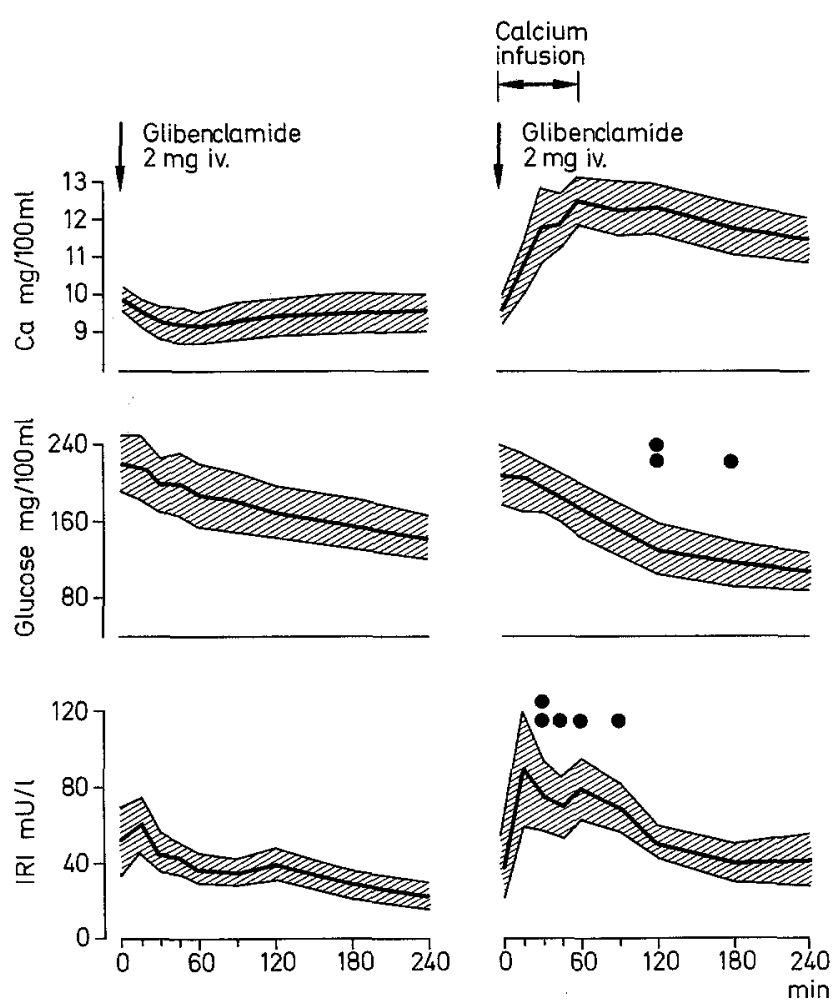

Fig. 1. Changes in serum calcium, blood glucose and IRI in 11 diabetic patients following glibenclamide (left) and glibenclamide + calcium administration (right).

Means with standard deviations (hatched area) are represented.

$\bullet=\mathrm{P}<0.05 ;:=\mathrm{P}<0.01$

(Significance of the decreases in serum calcium in the glibenclamide test is shown in Table 3) and venous blood samples were taken through an indwelling cannula before and $15,30,45,60,90$, 120,180 and 240 minutes after the IV injection for the measurement of calcium, glucose and immunoreactive insulin (IRI). In the three insulintreated patients only glucose and calcium were determined. Three to four days later the test was repeated with the addition of a simultaneous calcium chloride infusion $\left(10 \mathrm{mg} \mathrm{Ca}{ }^{++} / \mathrm{kg}\right.$ body wt in 500 $\mathrm{ml} 0.154 \mathrm{~mol} / 1$ saline) into a contralateral vein during the first hour of the test. In the intervening 3-4 days the same drug treatment was given and was interrupted again 24 hours prior to the second test. In a few cases the combined glibenclamide-calcium test was performed first to exclude nonspecific effects secondary to hospitalization (more regular life and diet patterns, reduction in physical activity, etc.). However, reversal of the timing of the test did not affect the results.

In order to investigate the effect of calcium alone, calcium infusion was repeatedly given without glibenclamide to three of the orally treated patients. This caused no change in plasma insulin levels.

Serum calcium was determined according to Ray Sarkar and Chauhan [22], blood glucose by the o-toluidine method, IRI by a double antibody technique using Boehringer Insulin-RIA Test Combination. Glibenclamide for IV use was kindly supplied by the Boehringer Company (Boehringer Mannheim GmbH, Mannheim, Germany).

All the data obtained following the test injection were compared to the initial ( 0 -minute) values and the means of the changes were calculated for each time-point. Differences between values belonging to identical time-points in the glibenclamide and the 
glibenclamide-calcium test as well as the significance of the decrease in serum calcium during the glibenclamide test were analyzed using Student's t-test.

\section{Results}

The changes in serum calcium, blood glucose and IRI following the glibenclamide administration are shown in the Figure (left part). Calcium concentrations decreased significantly (Table 3). Blood glucose decreased throughout the four-hour test. IRI levels showed a slight increase at 15 minutes and another smaller increase occurred at 120 minutes.

The changes in the above variables during the combined glibenclamide-calcium test are shown on the right side of the Figure. The fasting blood glucose concentration was not significantly different from that observed in the simple glibenclamide test, but the decrease was more pronounced, differences between the two tests being statistically significant at 120 and 180 minutes $(\mathrm{P}<0.01$ and $\mathrm{P}<0.05$, respectively). The rises in IRI were also significantly higher in the combined test at $30,45,60$, and 90 minutes $(\mathrm{P}<0.01,<0.05,<0.05$ and $\mathrm{P}<0.02$, respectively). The shape of the curve resembled the insulin response of normal subjects. Serum calcium increased following the calcium infusion as expected.

The time courses of calcium and blood glucose in the three insulin-treated patients are shown in Table 2. When calcium was also added the decreases in blood glucose were greater in each case (no mathematical analysis was carried out for three cases). The decreases in serum calcium during the glibenclamide test is shown in Table 3. Highly significant differences occurred at several intervals.

\section{Discussion}

Though the significance of calcium for insulin release in vitro is widely accepted there is uncertainty about the direct relationship between serum calcium and insulin secretion in vivo. Littledike et al. observed subnormal insulin output in postparturient hypocalcaemic cows [15]. Laron and Rosenberg reported on a boy whose arginine-stimulated insulin release was inhibited by severe hypocalcaemia [13]. Similar findings have been reported by Rizvi et al. [23]. In patients with parathyroid disorder Yasuda et al. found a significant correlation between the alterations of serum calcium and glucose-stimulated insulin secretion [24].

On the other hand Ziegler et al. found only a slightly decreased insulin response in EDTA-induced hypocalcaemia [25]. Lisch et al. observed normal glucose disappearence and insulin secretion in azotaemic, hypocalcaemic subjects, and in a subgroup of their patients insulin secretion was even reduced by calcium infusion [14]. In our earlier study the insulin response to oral glucose load in chronically hypocalcaemic patients was normal and unaffected by calcium injection [3]. Recently Harter has demonstrated that in Parathyroid hormone-treated dogs glucose-stimulated insulin release was increased by hypophosphataemia, but not by hypercalcaemia. However, tolbutamide-induced insulin release was unaffected by hypophosphataemia and increased by hypercalcaemia [5]. This observation reflects the different insulinotrophic action of glucose and tolbutamide, but fails to solve the contradiction between in vitro and in vivo results on the one hand and the above mentioned in vivo findings on the other.

Though in the present study the glibenclamideinduced insulin release was significantly potentiated by calcium infusion the exact mechanism of this potentiation is not clear.

Kim et al. observed an augmented insulin response to tolbutamide in hypercalcaemic patients with parathyroid disorder, but they attributed this response to the endogenous insulin resistance observed in this disease [8]. However, this could not be the explanation in the acute situation, since Ziegler et al. and Lisch et al. found significantly improved glucose assimilation in acutely induced hypercalcaemia $[25,14]$. Moreover, calcium ions were found to influence positively the activity of insulin-dependent enzymes such as adipose tissue protein kinase, phosphoprotein phosphatase and glycogen synthetase $[1,9]$. Thus it seems likely that insulin resistance in hyperparathyroidism is independent of hypercalcaemia and may be secondary to hyperglucagonaemia, which is often associated with the disease [19]. On the other hand, the significantly enhanced insulin secretion during the combined glibenclamide-calcium administration in our study could be attributed to the hypercalcaemia itself. However, some indirect mechanism (prolongation of the half-life of a sulphonylurea derivative, for example) could not be excluded. Since calcium infusion without glibenclamide did not change insulin levels we think it a potentiating rather than an additive effect.

Though the significantly enhanced insulin response provides sufficient explanation for the greater fall in blood glucose in the glibenclamide-calcium test, taking into account the highly significant decreases in serum calcium during glibenclamide administration a further possible mechanism has to be considered. In our previous investigation insulin giv- 
en to patients subcutaneously resulted in an early fall in serum calcium preceding the fall in blood glucose [5a]. In the present study the decrease in serum calcium took place between the maximum rise in IRI and the maximum reduction in blood glucose. To our knowledge this decrease is not a direct effect of glibenclamide, but is secondary to endogenous insulin mobilization and the consequence of uptake and accumulation of calcium ions in the target (muscle, fat, liver) cells, similar to the mechanism described by Parsons et al. for Parathyroid hormone $[19,20]$. Calcium, while accumulating intracellularly, might mediate insulin action $[1,6,7,9,10,11]$. Hypercalcaemia, providing abundant supply for this accumulation, may enhance peripheral insulin action. Thus, in addition to increased insulin secretion a peripheral enhancement of insulin effect may also play a part.

Acknowledgement. The authors are grateful to Dr. A. Paksy and P. Vargha for performing the statistical analysis and to Mrs. E. Kovács for her technical assistance.

\section{References}

1. Clarce, P., Kissebah, A.H., Vydelingum, N., Hope-Gill, H., Tulloch, B., Fraser, T.R.: Regulation of glycogenolysis through changes in intracellular calcium. Horm. Metab. Res. 7, 525 (1974)

2. Curry, D.L., Bennett, L.L., Grodsky, G. M.: Requirement for calcium ion in insulin secretion by the perfused rat pancreas. Am. J. Physiol. 214, 174-178 (1968)

3. Gerö, L., Szalay, F., Steczek, K., Tamás, Gy. jr.: Effect of acute changes in serum calcium on glucose tolerance, blood glucose, IRI and cortisol levels. Horm. Metab. Res. 8, 151-152 (1976)

4. Grodsky, G. M., Bennett, L. L.: Cation requirements for insulin secretion in the isolated-perfused pancreas. Diabetes $\mathbf{1 5}$, 910-913 (1966)

5. Harter, H. R., Santiago, V. J., Rutherford, W. E., Slatopolsky, E., Klahr, S.: The relative roles of calcium, phosphorus and parathyroid hormone in glucose- and tolbutamide-mediated insulin release. J. Clin. Invest. 58, 359-367 (1976)

5a. Holló, I., Gerö, L., Szalay, F., Korányi, L., Steczek, K., Tamás, Gy. jr.: Relationship between serum calcium and carbohydrate metabolism. Diabetologia 11, 344 (1975) (Abstr.)

6. Hope-Gill, H., Vydelingum, N., Kissebah, A.H., Tulloch, B. R., Fraser, T.R.: Simulation and enhancement of the adipose tissue insulin response by procaine hydrochloride: evidence for a role of calcium in insulin action. Horm. Metab. Res. 6, 457-462 (1974)

7. Hope-Gill, H., Kissebah, A. H., Tulloch, B., Clarce, P., Vydelingum, N., Fraser, T.R.: The effects of insulin on adipocyte calcium flux and the interaction with the effects of dibutyryl cyclic AMP and adrenaline. Horm. Metab. Res. 7, 194-196 (1975)

8. Kim, H., Kalkhoff, R.K., Costrini, N. V., Cerletty, J.M., Jacobson, M.: Plasma insulin disturbances in primary hyperparathyroidism. J. Clin. Invest. 50, 2596-2605 (1971)

9. Kissebah, A.H., Vydelingum, N., Tulloch, B. R., Hope-Gill, H., Fraser, T.R.: The role of calcium in insulin action. I. Purification and properties of enzymes regulating lipolysis in human adipose tissue: effects of cyclic AMP and calcium ions. Horm. Metab. Res. 6, 247-255 (1974)

10. Kissebah, A.H., Hope-Gill, H., Vydelingum, N., Tulloch, B. R., Clarce, P.V., Fraser, T. R.: Mode of insulin action. Lancet 1975 I, 144-147

11. Kissebah, A.H., Clarce, P., Vydelingum, N., Hope-Gill, H., Tulloch, B., Fraser, T. R.: The role of calcium in insulin action. III. Calcium distribution in fat cells; its kinetics and the effects of adrenaline, insulin and procaine-HCl. Eur. J. Clin. Invest. 5, 339-349 (1975)

12. Lambert, A.E., Jeanrenaud, B., Junod, A., Renold, A.E.: Organ culture of fetal rat pancreas II. Insulin release induced by amino and organic acids, by hormonal peptides, by cationic alterations of the medium and by other agents. Biochim. Biophys. Acta 174, 540-547 (1969)

13. Laron, Z., Rosenberg, Th.: Inhibition of insulin release and stimulation of growth hormone release by hypocalcemia in a boy. Horm. Metab. Res. 2, 121-122 (1970)

14. Lisch, H.J., Bolzano, K., Patsch, J., Sailer, S., Braunsteiner, $\mathrm{H}$.: Interaction between serum calcium concentration and glucose tolerance in normal and azotemic patients. Diabetologia 9, 467-471 (1973)

15. Littledike, E. T., Witzel, D. A., Whipp, S.C.: Insulin: Evidence for inhibition of release in spontaneous hypocalcemia. Proc. Soc. Exp. Biol. Med. 129, 135-139 (1968)

16. Malaisse, W.J., Malaisse-Lagae, F.: A possible role for calcium in the stimulus-secretion coupling for glucose-induced insulin secretion. Acta Diabetol. Lat. 7, (Suppl. 1.), 264-275 (1970)

17. Malaisse, W.J.: Insulin secretion: multifactorial regulation for a single process of release. Diabetologia 9, 167-173 (1973)

18. Milner, R.D. G., Hales, C. N.: The role of calcium and magnesium in insulin secretion from rabbit pancreas studied in vitro. Diabetologia 3, 47-49 (1967)

19. Paloyan, E.: Recent development in the early diagnosis of hyperparathyroidism. Surg. Clin. North Am. 47, 61-66 (1967)

20. Parsons, J. A., Near, R. M., Potts, J. T.: Initial fall of plasma calcium after intravenous injection of parathyroid hormone. Endocrinology 89, 735-740 (1971)

21. Parsons, J. A., Robinson, C. J.: Calcium shift into bone causing transient hypocalcaemia after injection of parathyroid hormone. Nature 230, 581-582 (1971)

22. Ray Sarkar, B.C., Chauhan, U.P.S.: A new method for determining microquantities of calcium in biological materials. Anal. Biochem. 20, 155-158 (1967)

23. Rizvi, S.N. A., Bansal, S., Rao, M. B., Vaishnava, H.: Effect of hypocalcaemia on glucose tolerance, insulin release and free fatty acid levels in human subjects. Postgrad. Med. J. 51, 471-475 (1975)

24. Yasuda, K., Hurukawa, Y., Okuyama, M., Kukuchi, M., Yoshinaga, K.: Glucose tolerance and insulin secretion in patients with parathyroid disorders. N. Engl. J. Med. 292, 501-504 (1975)

25. Ziegler, R., Bellwinkel, S., Schmidtchen, D., Minne, H.: Effects of hypercalcemia, hypocalcemia and calcitonin on glucose stimulated insulin secretion in man. Horm. Metab. Res. 4, 60 (1970)

Received: November 8, 1976, and in revised form:

March 28, 1977

\section{Dr. L. Gerß̋}

1st Department of Medicine

Semmelweis University

H-1083 Budapest

Korányi S. u. $2 / a$

Hungary 